\title{
Identification and characterization of secreted and pathogenesis-related proteins in Ustilago maydis
}

\author{
Olaf Müller · Peter H. Schreier · Joachim F. Uhrig
}

Received: 23 August 2007 / Accepted: 11 September 2007 / Published online: 5 October 2007

(C) Springer-Verlag 2007

\begin{abstract}
Interactions between plants and fungal pathogens require a complex interplay at the plant-fungus interface. Extracellular effector proteins are thought to play a crucial role in establishing a successful infection. To identify pathogenesis-related proteins in Ustilago maydis we combined the isolation of secreted proteins using a signal sequence trap approach with bioinformatic analyses and the subsequent characterization of knock-out mutants. We identified 29 secreted proteins including hydrophobins and proteins with a repetitive structure similar to the repellent protein Rep1. Hum3, a protein containing both, a hydrophobin domain and a repetitive Rep1-like region, is shown to be processed during passage through the secretory pathway. While single knock-outs of hydrophobin or repellent-like genes did not affect pathogenicity, we found a strong effect of a double knock-out of hum 3 and the repetitive $r s p 1$. Yeast-like growth, mating, aerial hyphae formation and surface hydrophobicity were unaffected in this
\end{abstract}

Communicated by R. Fischer.

O. Müller · P. H. Schreier · J. F. Uhrig

Max Planck Institute for Plant Breeding Research,

Carl-von-Linné Weg 10, 50829 Koeln, Germany

Present Address:

O. Müller

Department of Regine Kahmann,

Max Planck Institute for Terrestrial Microbiology,

35043 Marburg, Germany

P. H. Schreier

Bayer Cropscience, Alfred Nobel Str. 50,

40789 Monheim, Germany

J. F. Uhrig ( $\square)$

University of Cologne, Gyrhofstr. 15, 50931 Köln, Germany

e-mail: Joachim.Uhrig@uni-koeln.de double mutant. However, pathogenic development in planta stops early after penetration leading to a complete loss of pathogenicity. This indicates that Hum3 and Rsp1 are pathogenicity proteins that share an essential function in early stages of the infection. Our results demonstrate that focusing on secreted proteins is a promising way to discover novel pathogenicity proteins that might be broadly applied to a variety of fungal pathogens.

Keywords Hydrophobin - Repellent proteins · Phytopathogenic $\cdot$ Virulence factors $\cdot$ Signal sequence trap

\section{Introduction}

In plant-fungus interactions, establishing a successful infection requires intricate signal exchanges at the plant surface and the intercellular space interface (Hahn and Mendgen 2001). In the early phases of infection, reception and transduction of external signals play a key role in triggering developmental and morphogenetic processes preceding penetration of the host epidermis (Lucas 2004; Read et al. 1997; Tucker and Talbot 2001). Signal transduction, morphogenesis and manipulation of the host plant are facilitated through a diversity of extracellular effector molecules and morphogenic proteins. Such molecules are secreted into the intercellular interface between the pathogen and the plant or delivered inside the host cell (Lucas 2004). The analysis of whole-genome sequences of phytopathogenic fungi supports the particular importance of secreted proteins, and discovery programs aiming at the identification of genes encoding extracellular proteins have been initiated successfully (Dean et al. 2005; Lucas 2004; Torto et al. 2003). Examples of extracellular or surface-localized proteins that have been associated with pathogenicity include 
hydrolytic enzymes, hydrophobins, metallothioneins and tetraspanins (Clergeot et al. 2001; Gourgues et al. 2004; Kazmierczak et al. 2005; Kim et al. 2005; Talbot et al. 1993; Tucker et al. 2004; Veneault-Fourrey et al. 2005). Significantly, the recently published complete genome sequence of the biotrophic fungus Ustilago maydis revealed the presence of 12 gene clusters encoding secreted proteins. These are in part co-regulated and are involved in pathogenicity thus in a way resembling bacterial pathogenicity islands (Kamper et al. 2006).

Ustilago maydis is the causative agent of corn smut disease (Banuett 1995). The yeast-like saprophytic form can easily be propagated in vitro and due to its genetic amenability $U$. maydis is becoming an increasingly important model organism for plant pathogenic basidiomycetes (Feldbrugge et al. 2004; Kahmann et al. 2000; Kahmann and Kamper 2004). U. maydis is a maize pathogen able to infect all plant organs. After attachment to the host surface, spores germinate and subsequently produce haploid sporidia which live saprophytically and proliferate by budding. Pathogenic development is tightly linked with and controlled by the mating type loci $a$ and $b$. The biallelic $a$-locus encodes a pheromone receptor system and controls cell recognition and mating of compatible haploid sporidia on the plant surface (Banuett and Herskowitz 1989; Bolker et al. 1992; Kahmann et al. 2000). The multiallelic b-locus encodes two divergently transcribed homeodomain proteins $\underline{b E a s t}$ and bWest (Gillissen et al. 1992) which, if provided by two compatible strains, assemble a heterodimeric transcription factor triggering further pathogenic development of the filamentous and infectious dikaryon (Brachmann et al. 2001; Romeis et al. 2000). Compatible sporidia with different $a$ and $b$ alleles can form conjugation hyphae and mate. Cell fusion gives rise to a dikaryotic infectious filament which forms appressoria and invades the plant through natural openings or by direct penetration of the cuticle (Snetselaar and Mims 1993). Once inside its host, an interaction zone is formed between the invaginated host plasma membrane and the branching dikaryon. Reprogramming of the plant cell growth induces formation of tumors wherein the fungus proliferates extensively. Sporulation occurs near the end of the pathogenic life cycle and dark pigmented teliospores burst out of dry tumors (Banuett and Herskowitz 1996; Christensen 1963).

A variety of molecular tools, including restriction enzyme mediated integration (REMI), enhancer trapping, transposon mutagenesis and the analysis of expression profiles have been applied to systematically search for genes and proteins involved in or required for the pathogenic development of U. maydis (Basse and Steinberg 2004; Kahmann and Kamper 2004). A number of pathogenicityrelated proteins have been identified, and considerable progress has been achieved in uncovering the key players and the signaling processes controlling the dimorphic switch and the pathogenic development, demonstrating the involvement of cAMP-dependent signaling and a specific MAP kinase cascade (Brachmann et al. 2003; Muller et al. 1999). However, in most cases, loss-of-function mutants exhibit only reduced virulence and pleiotropic aberrant phenotypes like loss of surface hydrophobicity or morphological defects, not directly related to pathogenicity. So far, few "true" virulence factors have been reported for U. maydis, and little is known about how the signaling networks actually drive pathogenic development, and which factors at the interface between host and pathogen are involved. The discovery of 12 distinct gene clusters comprising nearly $20 \%$ of the secreted proteins of $U$. maydis, and the finding that deletion of entire clusters affects virulence in five cases support the importance of extracellular proteins and indicates that focusing on secreted proteins promises to be instrumental in increasing our understanding of fungal disease strategies.

We have isolated secreted proteins by combining a yeast-based screening method with bioinformatic analyses to identify candidate genes for proteins targeted to the secretory pathway. In this report, we provide evidence for an essential role of proteins of the hydrophobin and repellent classes for early stages of the pathogenic development of U. maydis.

\section{Methods}

Strains and growth conditions

Escherichia coli K12 strain DH5 $\alpha$ (Invitrogen, Karlsruhe, Germany) was used for DNA-library construction and general cloning of plasmids. $U$. maydis wild type strains 521 $(a 1 b 1)$ and $518(a 2 b 2)$ were grown at $28^{\circ} \mathrm{C}$ in YEPS (Tsukuda et al. 1988) or potato dextrose (PD) medium (Difco, Sparks, MD, USA). Mating of compatible strains was carried out on solid PD medium containing $1 \%$ charcoal at $22^{\circ} \mathrm{C}$ for $48 \mathrm{~h}$ (Holliday 1961). S. cerevisiae strain BY4741 (MATa, his $3 \Delta 1$, leu $2 \Delta 0$, met $15 \Delta 0$, ura $3 \Delta 0$, suc $2 \Delta 0$; Euroscarf, Germany) was used for yeast signal sequence trap experiments and grown at $30^{\circ} \mathrm{C}$ in complete media (YPAD), selective dropout media without uracil ( $\mathrm{SD}^{-\mathrm{URA}}$, Ausubel et al. 1987) or sucrose media (YEPSA, Klein et al. 1996), respectively.

\section{DNA and cloning procedures}

DNA manipulations followed standard protocols (Sambrook et al. 1989). Isolation of chromosomal DNA of $U$. maydis was carried out as described (Hoffmann and Winston 1987). For library construction chromosomal DNA of 
$U$. maydis strain 521 was randomly fragmented by partial DNase I (Roche Diagnostics, Manheim, Germany) digestion in presence of $\mathrm{MnCl}_{2}$. The resulting blunt ended DNA fragments were ligated to EagI adaptors (5'-CTGAAC TCGCTGAAGATAAC-3' and 5'-GGCCGTTATCTTCA GCGAGTTCAG-3') and cloned into NotI digested signal sequence trap vector pRK18 (Klein et al. 1996). Subsequent transformation in $E$. coli resulted in a library of $1 \times 10^{6}$ independent clones. Labeling of DNA and transformation of $U$. maydis and $S$. cerevisiae was performed according to published protocols (Gietz et al. 1995; Schulz et al. 1990).

\section{Bioinformatic analyses}

Bioinformatic prediction of subcellular protein localization was done as described (Kamper et al. 2006). The occurrence of secretory targeting signals (signal peptides) was predicted using signalP (v. 3.0) which takes into account the N-terminal region (70 aa) of the protein sequence (Bendtsen et al. 2004). ProtComp (v. 6.0; http://www.softberry.com) analyzes the entire protein sequence, and the integral prediction score was used to predict subcellular localization.

\section{Construction of $U$. maydis knockout strains}

Deletion mutants were generated by gene replacement following a PCR-based strategy as described earlier (Kamper 2004). Flanking DNA regions of $\sim 1 \mathrm{~kb}$ were amplified (see primers in Table 2) and fused to a hygromycin $\mathrm{B}\left(\mathrm{Hyg}^{+}\right)$or, in the case of double knockouts, Nourseothricin $\left(\mathrm{NAT}^{+}\right.$) resistance cassette. The construct was subsequently transformed into $U$. maydis, and homologous integration was proven by southern analysis using DIG-labeled flanking DNA regions as a probe. Deletion strains constructed in this study are summarized in Table 1.

\section{Protein expression in $U$. maydis}

The coding sequences were amplified (see primers in Table 2) and cloned in pCA123 (Leuthner et al. 2005) to obtain a translational fusion with eGFP (Clontech) expressed from the constitutive otef promoter (Spellig et al. 1996). Constructs were integrated into the $U$. maydis genome, and protein expression was monitored by Western analysis.

\section{Yeast signal sequence trap}

S. cerevisiae strain BY4741 was transformed with the genomic $U$. maydis library $(1 \mu \mathrm{g}$ plasmid DNA/ $5 \times 10^{7}$ cells) resulting in $>1 \times 10^{6}$ yeast transformants which were plated on solid $\mathrm{SD}^{-\mathrm{URA}}$ medium. After $60 \mathrm{~h}$
Table $1 U$. maydis gene deletion strains constructed and used in this study

\begin{tabular}{|c|c|c|}
\hline Strain & Genotype & Resistance \\
\hline 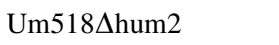 & $a 2 b 2 \Delta h u m 2$ & $\mathrm{Hyg}^{\mathrm{R}}$ \\
\hline Um521 $\Delta$ hum2 & alb1 1 hum 2 & $\operatorname{Hyg}^{\mathrm{R}}$ \\
\hline Um518 hum3 & $a 2 b 2 \Delta h u m 3$ & $\operatorname{Hyg}^{R}$ \\
\hline Um521 $\Delta$ hum3 & alb1 $\operatorname{shum3}$ & $\operatorname{Hyg}^{\mathrm{R}}$ \\
\hline 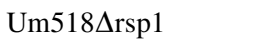 & $a 2 b 2 \Delta r s p 1$ & $\operatorname{Hyg}^{\mathrm{R}}$ \\
\hline $\mathrm{Um} 521 \Delta \mathrm{rsp} 1$ & albldrspl & $\operatorname{Hyg}^{\mathrm{R}}$ \\
\hline $\mathrm{Um} 518 \Delta \mathrm{rsp} 2$ & $a 2 b 2 \Delta r s p 2$ & $\operatorname{Hyg}^{\mathrm{R}}$ \\
\hline $\mathrm{Um} 521 \Delta \mathrm{rsp} 2$ & $a 1 b 1 \Delta r s p 2$ & $\mathrm{Hyg}^{\mathrm{R}}$ \\
\hline Um521-hum3-GFP & alb1hum3:eGFP & $\mathrm{Cbx}^{\mathrm{R}}$ \\
\hline Um518 hum $3 \Delta$ hum 2 & $a 2 b 2 \Delta h u m 3 \Delta h u m 2$ & $\operatorname{Hyg}^{R} \mathrm{Nat}^{R}$ \\
\hline Un521 $\Delta$ hum $3 \Delta$ hum 2 & albldhum $3 \Delta$ hum 2 & $\mathrm{Hyg}^{\mathrm{R}} \mathrm{Nat}^{\mathrm{R}}$ \\
\hline $\mathrm{Um} 518 \Delta$ hum $3 \Delta \mathrm{rsp} 1$ & $a 2 b 2 \Delta$ hum $3 \Delta$ hum 2 & $\mathrm{Hyg}^{\mathrm{R}} \mathrm{Nat}^{\mathrm{R}}$ \\
\hline $\mathrm{Um} 521 \Delta$ hum $3 \Delta \mathrm{rsp} 1$ & alb1 1 hum $3 \Delta r s p 1$ & $\mathrm{Hyg}^{\mathrm{R}} \mathrm{Nat}^{\mathrm{R}}$ \\
\hline Um518 $\Delta$ hum3 $3 \Delta$ rep 1 & $a 2 b 2 \Delta h u m 3 \Delta$ rep1 & $\mathrm{Hyg}^{\mathrm{R}} \mathrm{Nat}^{\mathrm{R}}$ \\
\hline $\mathrm{Um} 521 \Delta$ hum $3 \Delta \mathrm{rep} 1$ & 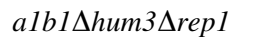 & $\mathrm{Hyg}^{\mathrm{R}} \mathrm{Nat}^{\mathrm{R}}$ \\
\hline
\end{tabular}

incubation at $30^{\circ} \mathrm{C}$, transformants were replica-plated onto YEPSA plates. After 3 to 10 days incubation at $30^{\circ} \mathrm{C}$ colonies were transferred to $\mathrm{SD}^{-\mathrm{URA}}$ plates. Plasmid inserts of genomic $U$. maydis DNA were amplified by colony PCR and sequenced.

Immunodetection

$U$. maydis strains were grown in YEPS medium to an $\mathrm{OD}_{600}$ of 0.3. Cell sediments and supernatants were collected separately after centrifugation. Supernatants were filtered through a $0.2 \mu \mathrm{m}$ cell filter, proteins were precipitated with TCA (10\%), washed in acetone and dissolved in PBS with proteinase inhibitor (Complete, Roche). Cells were resuspended in PBS with proteinase inhibitor, frozen in liquid nitrogen and disrupted with glass beads. After centrifugation, supernatants were stored at $-20^{\circ} \mathrm{C}$. After SDS page proteins were transferred to polyvinylidenedifluoride membrane (Millipore). Binding of the primary antibody (monoclonal GFP IgG mouse; Roche) was detected using rabbit anti mouse IgGHRP conjugate (Promega) and the ECL+ plus Chemiluminescence kit (Amersham Pharmacia Biotech).

Plant infection

Infections of Zea mays var. Gaspar Flint were carried out as described previously (Gillissen et al. 1992), either by dropping suspensions of compatible sporidia onto the apex of 14 day old plants or by injection of the suspension into 7 day old seedlings using a $1 \mathrm{ml}$ syringe with an 18-gauge needle. Infected plants were assessed for disease symptoms 7-21 days after infection, and $\mathrm{H}_{2} \mathrm{O}_{2}$ analysis in infected 
Table 2 Oligonucleotides used in this study

\begin{tabular}{|c|c|c|}
\hline Primer & Sequence $\left(5^{\prime} \rightarrow 3^{\prime}\right)$ & Site \\
\hline \multicolumn{3}{|l|}{ Library construction } \\
\hline Eag_fwd & CTGAACTCGCTGAAGATAAC & \\
\hline Eag_rev & GGCCGTTATCTTCAGCGAGTTCAG & \\
\hline \multicolumn{3}{|l|}{ Gene disruption } \\
\hline REP1-lb_Fwd & TTTGCGTATTCCACCTGCAGTAGCC & \\
\hline REP1-lb_Rev & CACGGCCTGAGTGGCCAAGAGAGTGTGATTCTTGCGAGCGG & SfiI \\
\hline REP1-rb_Fwd & GTGGGCCATCTAGGCCTGCTTGCAGATCGCTATGCAGATGG & SfiI \\
\hline REP1-rb_Rev & CAACTACTGGGAAAAGTATGGAGCGG & \\
\hline HUM2-lb_Fwd & ACATTCAGCAAACAGCAAATGACCC & \\
\hline HUM2-lb_Rev & CACGGCCTGAGTGGCCGCTGAAGAGCTAGAGAGTGTGGTTGG & SfiI \\
\hline HUM2-rb_Fwd & GTGGGCCATCTAGGCCGTCGTGACTGCTCGCTCTCTTTCC & SfiI \\
\hline HUM2-rb_Rev & TGACGTGCTGGCTAAGTTGTCGC & \\
\hline RPH1-lb_Fwd & CGGAAAGGGATGTCTTGGTTGTTAC & \\
\hline RPH1-lb_Rev & CACGGCCTGAGTGGCCAGGCAGTTGATTGGTGTTTGGATAG & SfiI \\
\hline RPH1-rb_Fwd & GTGGGCCATCTAGGCCTTTGGTTCGCATTCTGGTTTCGTC & SfiI \\
\hline RPH1-rb_Rev & ATGTGAAGTACAAACTTCGGCGTGC & \\
\hline RSP1-lb_Fwd & ACCGAGGCTATGGTTCTTCTAGTCC & \\
\hline RSP1-lb_Rev2 & CACGGCCTGAGTGGCCGTGAAGAGATGCTGCTGCGAGAGG & SfiI \\
\hline RSP1-rb_Fwd2 & GTGGGCCATCTAGGCCTGTACGCTCTTTCTCGCTCACAACC & SfiI \\
\hline RSP1-rb_Rev & TCTACTAACCGAAGGCTCTGACCTGG & \\
\hline RSP2-lb_Fwd & TCTCCCACACTAACCTGAATGAGAGC & \\
\hline RSP2-lb_Rev & CACGGCCTGAGTGGCCTATAAGAGGTTGGTGACGATGGTGG & SfiI \\
\hline RSP2-rb_Fwd & GTGGGCCATCTAGGCCCTGGTTGTGCTTCGTTTTAGTTTGC & SfiI \\
\hline RSP2-rb_Rev & AAGCAGAATCTGGTCCATACAAATCG & \\
\hline \multicolumn{3}{|l|}{ eGFP fusion } \\
\hline RPH1-GFP_Fwd & GAGAGAGGATCCATGAAGTACCTTCAGTTCCTCGCTG & BamHl \\
\hline RPH1-GFP_Rev & GAGAGACCATGGAGTTGATAGGGATCGAAGTGCAGC & NcoI \\
\hline
\end{tabular}

plant tissue was performed according to Thordal-Christensen and coworkers (1997).

\section{Microscopy}

Infected leaf tissue was excised from regions adjacent to injection holes generated by infections with a syringe. Microscopy of leaf tissues and $U$. maydis GFP-reporter strains as well as processing of images was performed as described earlier (Basse et al. 2000). Cell wall components were stained with $2 \mathrm{mg} / \mathrm{ml}$ Calcofluor-white (Sigma) in PBS or $0.03 \%$ Chlorazole Black E solution (Sigma), respectively.

\section{Results}

Identification of secreted proteins from $U$. maydis

To identify genes encoding proteins directed to the secretory pathway, a genomic fragment library was constructed and screened applying the yeast signal sequence trap system (Klein et al. 1996). This method is based on the reconstitution of extracellular invertase activity by gene fragments fused to the $5^{\prime}$-end of a truncated invertase gene. Sequences encoding functional signal peptides are identified by growth of yeast colonies on media containing sucrose as the sole carbon source (Klein et al. 1996). Genomic DNA from the haploid wild type strain Um521 (alb1) was randomly fragmented and fragments of the desired average size of $\sim 300$ bp were integrated into pRK18 (Klein et al. 1996). The resulting library of $1.1 \times 10^{6}$ independent clones was screened twice resulting in the isolation of 192 yeast colonies growing on sucrose media. Plasmid insertions were amplified by yeast colony PCR, and sequencing revealed 52 unique genomic DNA clones designated as yeast signal sequence trap (YSSTs). Candidate fragments were retransformed into yeast strain BY4741 and serial dilutions were spotted onto selection media. In all cases the results from the screenings could be confirmed (two examples are shown in Fig. 1).

Of these candidates, 28 corresponded to predicted $5^{\prime}$-ends of annotated genes and one candidate (YSST83) to 

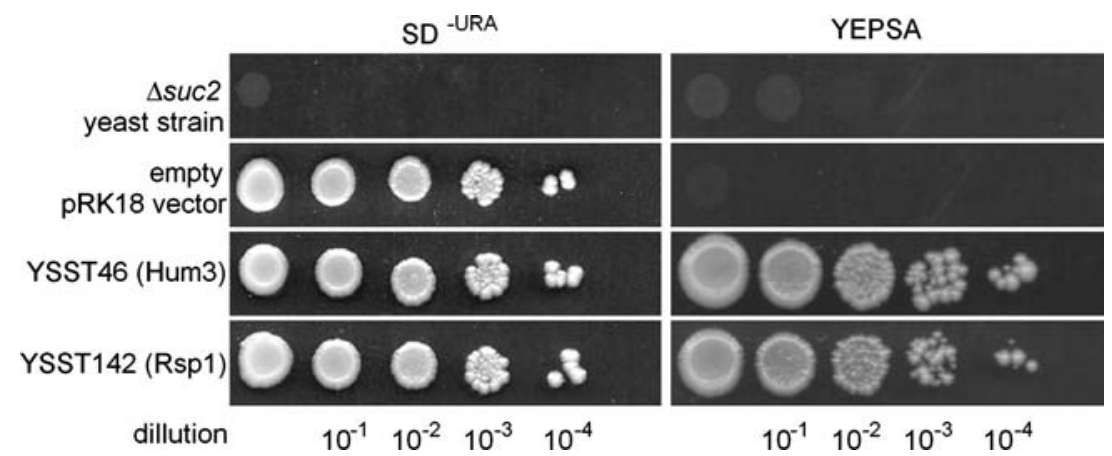

Fig. 1 Selection of secreted proteins using the yeast signal sequence trap. Strains were diluted and spotted on $\mathrm{SD}^{-\mathrm{URA}}$ or sucrose media (YEPSA) respectively and incubated 5 days at $30^{\circ} \mathrm{C}$. Clones with functional signal peptides (exemplarily shown YSST46, YSST142) were able to grow on media with sucrose as the only carbon source. $\Delta$ suc2 yeast strains not transformed or transformed with empty pRK18, respectively, were used as negative controls

the 5' region of an EST clone from germinating teliospores (Sacadura and Saville 2003). The other 23 clones selected with the yeast signal sequence trap method encoded either internal membrane spanning regions of membrane proteins or represent non-coding genomic sequences, and were not considered further.

The 29 candidates representing the N-termini of annotated proteins are consistently predicted to be targeted to the secretory pathway by the combined application of different bioinformatic algorithms predicting signal peptides or subcellular localization (Table 3). These candidates include HUM2 and REPI encoding a hydrophobin and a repellent protein, respectively, previously described as secreted proteins in U. maydis involved in hydrophobic surface interactions of fungal hyphae (Teertstra et al. 2006; Wosten et al. 1996). Repellent proteins are characterized by repeated amino acid sequences separated by Kex2-like proteolytic cleavage sites, and have been proposed to fulfill similar functions as hydrophobins (Kershaw and Talbot 1998; Wosten et al. 1996). Candidate YSST46 designated as Hum3 (Teertstra et al. 2006) is an unusual protein combining a repetitive Rep1-like structure and a C-terminal region showing high homology to Hum2 (Teertstra et al. 2006, Fig. 2a, b). YSST142 designated as Rsp1 (repetitive secreted protein 1) was identified as another protein with internal repeats (Fig. 2d, e). Although Rep1, Hum3 and Rsp1 showed no sequence homology, they share the common structural pattern of internal repeats separated by putative Kex 2 processing sites. The Rsp1 sequence contains 11 virtually identical repeats with an equal length of 21 aa (with exception of the last repeat, Fig. 2e). Eight repeats end with the LKKR motif previously shown to be processed in Rep1 of $U$. maydis (Wosten et al. 1996). In contrast to Rep1 and Hum3, the repeats of Rsp1 are hydrophilic (Fig. 2c, f).

Bioinformatic analysis of the $U$. maydis genome with respect to this repetitive structural characteristic led to the identification of another putative protein of the Rep class designated Rsp2 that was included in our functional analyses (see below).

Further proteins identified with the yeast signal sequence trap include homologs of the mannoprotein MP88 from Cryptococcus neoformans (YSST13), putative cell wall proteins with expansion and phospholipase domains, respectively (YSST29, YSST67), hydrolytic enzymes and a number of unknown proteins (Table 3).

Hum 3 is secreted and processed between the repetitive and hydrophobin domains

The structure of Hum 3 combining a hydrophobin domain with a repellent protein-like repetitive domain strongly hints at a joint function of these two classes of proteins, which is inline with the recent finding that repellent proteins might evolutionary replace hydrophobins in certain ascomycetes (Teertstra et al. 2006). Therefore, the main focus of the described project was investigating the function of this protein. Hum 3 is a predicted protein of 828 aa with a repetitive repellent-like region of 578 aa separated from a hydrophoKex2 processing sites (Teertstra et al. 2006). The repetitive region contains 17 amphipathic repeats of 31-36 aa each with a C-terminal putative Kex 2 processing motif (Fig. $2 b$, c). While eight of the Kex 2 motifs end with a characteristic lysine-arginine or proline-arginine dipeptide, nine of these repeats contained a glutamic acid-arginine motive. Only the lysine-arginine motif (LKKR) has been proven to be processed in U. maydis, so far (Wosten et al. 1996). The hydrophobin domain of 117 aa contains eight conserved cysteine residues which are characteristic for fungal Class I hydrophobins (highlighted in Fig. 2b).

To assess secretion and processing experimentally, Hum 3 was fused to eGFP and expressed from the otef promoter that is constitutively active in sporidia. The fusion bin-like domain by a spacer region containing three possible 
Table 3 Identification of secreted proteins by yeast signal sequence trap (YSST) screening combined with bioinformatic analysis
Accession numbers (Acc.) according to MUMDB, release 11-2005 (http://mips.gsf.de/ genre/proj/ustilago/). Prediction: Sequences were analyzed with SignalP (v. 3.0) algorithms (neural network, NN, and hidden markov model, HM) and protcomp (v. 6.0; http://www. softberry.com, PC)

$S$ secretory pathway, $M$ mitochondrial protein, $O$ other localization

${ }^{a}$ EST library of germinating teliospores (Sacadura and Saville 2003)

\begin{tabular}{|c|c|c|c|c|c|}
\hline \multirow[t]{2}{*}{ YSST } & \multirow[t]{2}{*}{ Acc } & \multicolumn{3}{|c|}{ Prediction } & \multirow[t]{2}{*}{ Annotation } \\
\hline & & $\mathrm{NN}$ & $\mathrm{HM}$ & $\mathrm{PC}$ & \\
\hline 1 & UM05222 & $\mathrm{S}$ & $\mathrm{S}$ & $\mathrm{S}$ & Hypothetical protein \\
\hline 2 & UM10301 & $\mathrm{S}$ & $\mathrm{S}$ & $\mathrm{S}$ & Hypothetical protein \\
\hline 11 & UM11562 & $\mathrm{S}$ & $\mathrm{S}$ & $\mathrm{S}$ & Hydrophobin (Hum2) \\
\hline 13 & UM06162 & $\mathrm{S}$ & $\mathrm{S}$ & $\mathrm{S}$ & Immunoreactive mannoprotein (MP88) \\
\hline 14 & UM02295 & $\mathrm{S}$ & $\mathrm{S}$ & $\mathrm{S}$ & Hypothetical protein \\
\hline 17 & UM03138 & $\mathrm{S}$ & $\mathrm{S}$ & $\mathrm{S}$ & Hypothetical protein \\
\hline 27 & UM05295 & $\mathrm{S}$ & $\mathrm{S}$ & $\mathrm{S}$ & Hypothetical protein \\
\hline 29 & UM01513 & $\mathrm{S}$ & $\mathrm{S}$ & $\mathrm{S}$ & Riboflavin-aldehyde forming enzyme \\
\hline 30 & UM03392 & $\mathrm{S}$ & $\mathrm{S}$ & $\mathrm{S}$ & Hypothetical protein \\
\hline 31 & UM04035 & $\mathrm{S}$ & $\mathrm{S}$ & $\mathrm{S}$ & Hypothetical protein \\
\hline 33 & UM05622 & $\mathrm{S}$ & $\mathrm{S}$ & $\mathrm{S}$ & Conserved hypothetical protein \\
\hline 34 & UM01202 & $\mathrm{O}$ & $\mathrm{S}$ & $\mathrm{S}$ & Hypothetical protein \\
\hline 36 & UM00876 & $\mathrm{S}$ & $\mathrm{S}$ & $\mathrm{S}$ & Exo-1,3-beta-glucanase \\
\hline 46 & UM04433 & $\mathrm{S}$ & $\mathrm{S}$ & $\mathrm{S}$ & Hydrophobin (Hum3) \\
\hline 52 & UM01014 & $\mathrm{S}$ & $\mathrm{S}$ & $\mathrm{S}$ & Thioredoxin related protein \\
\hline 53 & UM05953 & $\mathrm{S}$ & $\mathrm{S}$ & $\mathrm{S}$ & Hypothetical protein \\
\hline 56 & UM00310 & $\mathrm{S}$ & $\mathrm{S}$ & $\mathrm{S}$ & Related to WD-repeat protein crb3 \\
\hline 62 & UM01165 & $\mathrm{S}$ & $\mathrm{S}$ & $\mathrm{S}$ & Related to Glucan 1,3-beta-glucosidase precursor \\
\hline 63 & UM03065 & $\mathrm{S}$ & $\mathrm{S}$ & M & Putative protein \\
\hline 67 & UM11266 & $\mathrm{S}$ & $\mathrm{S}$ & $\mathrm{S}$ & Probable lysophospholipase (lpl) \\
\hline 73 & UM01238 & $\mathrm{S}$ & $\mathrm{S}$ & $\mathrm{S}$ & Hypothetical protein \\
\hline 74 & UM06218 & $\mathrm{S}$ & $\mathrm{S}$ & $\mathrm{O}$ & Transglycosylase SLT domain protein \\
\hline 77 & UM03923 & $\mathrm{S}$ & $\mathrm{S}$ & $\mathrm{S}$ & Hypothetical protein \\
\hline 83 & $\mathrm{CD} 488380^{\mathrm{a}}$ & $\mathrm{S}$ & $\mathrm{S}$ & $\mathrm{S}$ & Hypothetical protein \\
\hline 101 & UM03924 & $\mathrm{S}$ & $\mathrm{S}$ & $\mathrm{S}$ & Repellent protein 1 precursor (Rep1) \\
\hline 102 & UM03046 & $\mathrm{S}$ & $\mathrm{S}$ & $\mathrm{S}$ & Hypothetical protein \\
\hline 142 & UM06112 & $\mathrm{S}$ & $\mathrm{S}$ & $\mathrm{S}$ & Hypothetical protein (Rsp1) \\
\hline 162 & UM00904 & $\mathrm{S}$ & $\mathrm{S}$ & $\mathrm{S}$ & Related to glucose regulated stress protein, Hsp70-like \\
\hline 169 & UM01976 & $\mathrm{S}$ & $\mathrm{S}$ & $\mathrm{S}$ & Hypothetical protein \\
\hline
\end{tabular}

construct was integrated into the $c b x$-locus of the haploid wild type strain Um521 (alb1). Western analysis using monoclonal anti-GFP antibodies verified the expression of the fusion construct (Fig. 3). In whole-cell extracts, signals were detected corresponding in size to the full-length fusion protein $(112 \mathrm{kDa})$, a fusion of the C-terminal hydrophobin-like domain with eGFP (40 kDa) and free eGFP (27 kDa). In the supernatant, however, only one single band could be detected corresponding to the $40 \mathrm{kDa}$ hydrophobin-eGFP fusion (Fig. 3). These results indicate that Hum 3 is indeed a secreted protein that it is processed in front of the hydrophobin domain.

Hum3 and Rsp1 are essential for pathogenic development

To reveal a possible role of hydrophobin and repellent-like genes in pathogenicity, deletion mutants of compatible haploid strains UM518 (a2b2) and UM521 (alb1) were gener- ated by gene replacement. Figure 4 illustrates the construction and genomic organization of the knock-out strains of hum3 and rsp1, respectively. Deletion mutants were tested for filamentous growth by mating assays on charcoal media and for pathogenic development by infecting maize plants. For each pathogenicity test at least 25 plants (192 in case of $\Delta h u m 3 \Delta r s p 1)$ were infected in two independent experiments and with at least two independent transformants. The single deletions of hum2, hum3, rsp1 or rsp2, respectively, had no apparent effect on mating, aerial hyphae formation, surface hydrophobicity and pathogenicity (Tables 4, 5). With respect to hum2 and hum3, these results confirm the recent findings of Teertstra et al. (2006), who additionally detected a partial reduction in aerial hyphae formation in the hum 2 knock-out mutant.

Deletion of repl has been shown previously to affect aerial hyphae formation, while mating and hyphae formation in an aqueous environment as well as pathogenicity and 
A

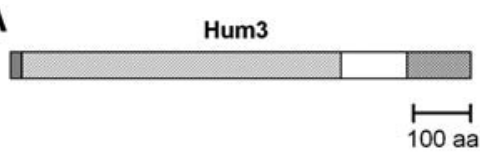

B 1 MKYLOELAAVAAVSAFSGPVLA---------$54---A I K V D N S A Q$ FVPVQGT IAALSAVLNEQKAGKR 86 ----SFSVENTNQVLPIDVI IAGLSQVLTEQKAAKR $118----D N I V K N T N Q I L P I E A T$ IAALSAIANGOKAATKR $151---$ STAVDNSSQFIPIQGTLAAFSNVLNSQKATKR 183 --NTGKVVDNTNQVVPIQGTLAALSTVLNEQKASKR $217----G V D V D N S S Q T L P I E A T$ I AALST IANGQQAGKR 249 NAPDFDVVKNSNQVLPIQATA.ALLSQIANGQSVEKR 285 NAPDFDVVKNSNQVLPIQATA.LLSQIANGQSVEKR 321 NAPDFDVVKNSNQVLPIQATAALLSQIANGQSVEKR 357 NAPDFDVYKNSNOVLPIOATAALLSOIANGOSVEKR 393 NAPDFDSVKNSNQVVPIQATAALLSAVKNLQSVER 428 NAPDFDSVKNSNQVVPIQATAALLSQIANGQSVEKR 464 NAPDFDSVKNSNQVVPIOGTAALLSVVGNGQSVSKR 500 HEGENNIVDNTNQVIPIQAT IAALSTLLNSQKAER $535---$ SYSVDNTNQVLPIEATLAAFSSVLNSQKAER $566---S Y S V E N D N E V V P V D L V A A A L S Q V A N G Q K V T R R$ $[\ldots]$

705 LKSLVKR

712 YAAEEDEAMAKRTPSLNGRGQRPRPRNSSSSEHNNNGOCS

752 VGEAKCCSQVITDEGKKKTLAGLLGENNLVGDIGLNCQQI

792 PVLGVSLQS ICKATPVCCTNVSQDGLVNVGC̣TSIPIN

c

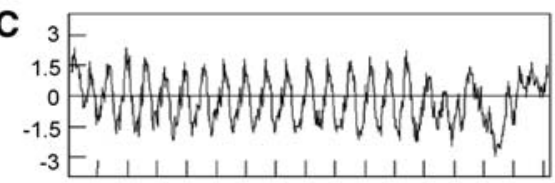

D

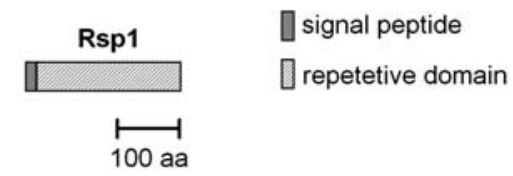

E

1 APTPASSKLATRYDGDIIDETNAALKDLGLKKR $(12+21)$

54 YDGDIIDETNAALKDLGLKKR (21)

75 YDGDIIDETNAALKDLGLKKR (21)

96 YDGDIIDKTNAALKDLGLKKR (21)

117 YDGDIIDETNAALKDLGLKKR (21)

138 YDGDIIDETNAALKDLGLKKR (21)

159 YDGDIIDETNAALKDLGLKKR (21)

180 YDGDIIDETNAALKDLGLKKR (21)

201 YEGDVLDEINGCLTSLGFRKR (21)

222 YEGDVLDELAAAEKEFGVRKR (21)

243 YEGDVLDAVNGCLKSLGL (19)

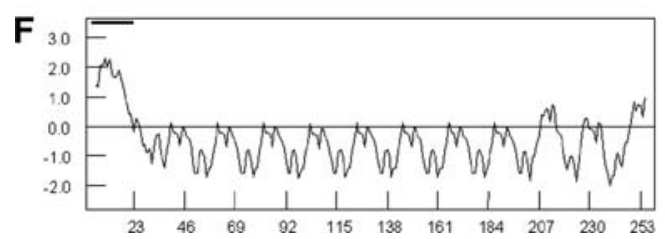

Fig. 2 Sequence and structural features of Hum 3 and Rsp1. a The repetitive repellent-like region of Hum 3 spans 578 aa and is separated from a hydrophobin-like domain by a spacer region containing three possible Kex 2 processing sites. The repetitive region contains 17 amphipathic repeats of 31-36 aa each of them with a C-terminal putative Kex 2 processing motif. $\mathbf{b}$ The hydrophobin domain of 117 aa contains eight conserved cysteine residues which are characteristic for fungal hydrophobins. c Hydropathy plot showing the amphipathic repeat sequences. d, e The repetitive Rsp1 contains 11 repeats of 19 aa which span the full length of the sequence expect for the signal peptide. The repeats are separated by putative KEX2 processing motifs. f In contrast to Hum 3 the repeat regions are not amphipathic but hydrophilic

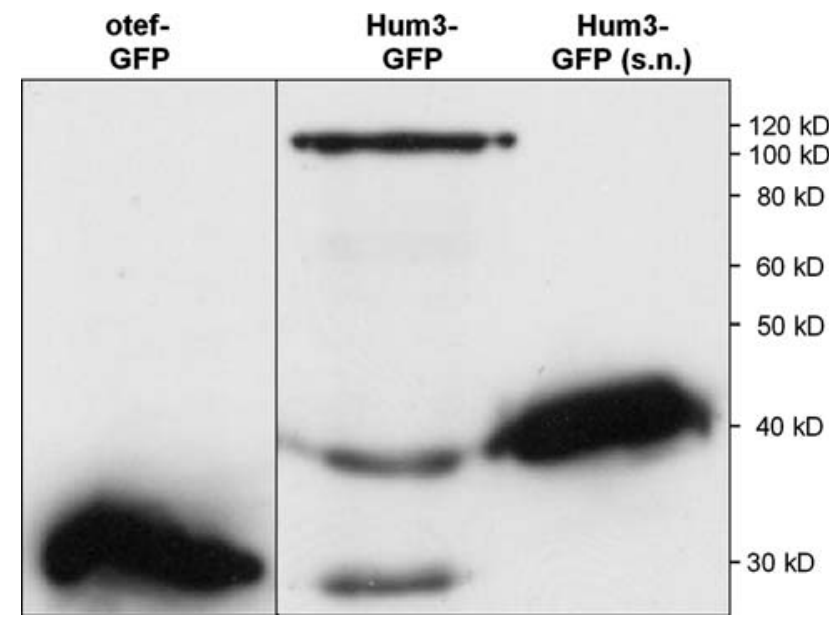

Fig. 3 Hum 3 is secreted and processed. Immunodetection of GFPfusion proteins in cell extracts and in cell-free supernatant. The Hum3protein was C-terminally fused to GFP (Hum3-GFP); pCA123 was integrated without fusion as a control (otef-GFP), showing the GFP signal at $27 \mathrm{kDa}$. In protein extracts from whole cells signals at 112 and $40 \mathrm{kDa}$ could be detected, corresponding to the full-length Hum 3 and the Hum3-hydrophobin domain fused to GFP, respectively. The additional band at $27 \mathrm{kDa}$ corresponds to GFP. In contrast, protein extracts from supernatants just show the $40 \mathrm{kDa}$ signal corresponding in size with the Hum3-hydrophobin domain fused to GFP, indicating that Hum 3 has a functional secretion signal in U. maydis and that Hum 3 is processed

formation and viability of teliospores were not affected (Wosten et al. 1996).

To assess the possibility of redundant functions of HUM3 and other hydrophobin and repetitive proteins, double knockout strains were constructed. Gene expression profiles revealed that $r s p l$ is expressed specifically in early stages of pathogenic development up to 5 days after plant infection, while $r s p 2$ is constitutively expressed during all stages of fungal development (Kamper and Vranes, MPI Marburg, personal communication). Repl and hum2 have previously been shown to be upregulated in the filamentous dikaryon (Teertstra et al. 2006). Therefore, double knockout strains of hum 3 and hum2, rep1 and rsp1, respectively, were investigated. The $\Delta$ hum $3 \Delta$ hum 2 deletion strains were not affected in formation of aerial hyphae, surface hydrophobicity (Fig. 5a) and pathogenic development (Table 4). A similar double knock-out strain has been described recently, and reduced formation of aerial hyphae due to a defect in fusion of compatible $\Delta$ hum $3 \Delta$ hum 2 partners has been observed (Teertstra et al. 2006). The double deletion of hum 3 and repl resulted in reduced development of aerial hyphae on charcoal media and loss of surface hydrophobicity (Fig. 5b). However, no effect on pathogenicity could be observed. This phenotype of the $\Delta$ hum $3 \Delta$ repl double mutant resembles the phenotype of the $\Delta$ repl single deletion described previously (Wosten et al. 1996). 


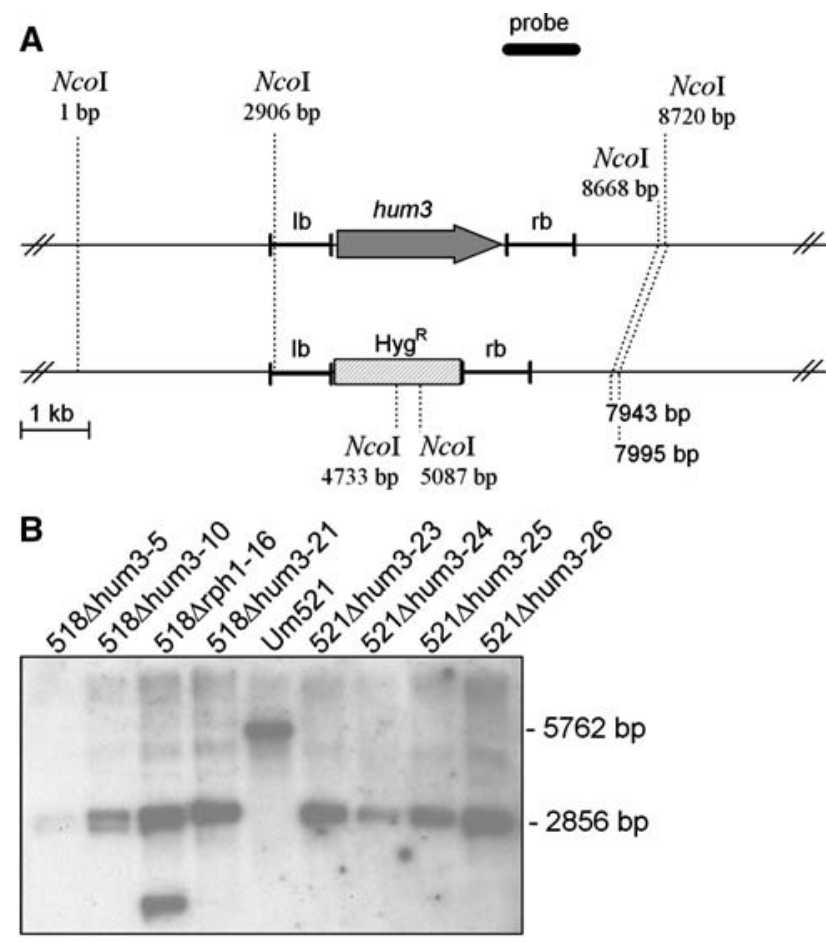

Fig. 4 Construction of knockout strains $\Delta h u m 3$ and $\Delta r s p 1$ by gene replacement. a, c schematic illustration of hum 3 and $r s p 1$ loci before and after homologous integration of the hygromycin disruption cassette. Amplified flanking regions which were ligated to the Hygromycin cassette $\left(\mathrm{Hyg}^{\mathrm{R}}\right)$ and restriction enzymes used in southern analysis are indicated. b, d Southern analysis. Genomic DNA from transformants and wild type strains were hybridized with DIG-dUTP labeled probes. The positions of the probes are indicated. Signals of the wild type locus (b hum3, 5,762 bp/d rsp1, 1,633 bp) and homologous integration of the hygromycin disruption cassette (b $\Delta h u m 3,2,856 \mathrm{bp} / \mathbf{d}$ $\Delta$ rsp 1, 3,696 bp) could be observed in the autoradiogram. Additional signals are due to ectopic integration events of the knockout cassette. For construction of double knockouts hum2, repl and rspl were replaced by $\mathrm{NAT}^{\mathrm{R}}$ disruption cassettes in compatible $\Delta$ hum 3 strains (data not shown). lf, $r f$ left, right flanking region

Table 4 Phenotypes of deletion mutants of repellent-like and hydrophobin genes

\begin{tabular}{|c|c|c|c|}
\hline & $\begin{array}{l}\text { Aerial } \\
\text { hyphae }\end{array}$ & $\begin{array}{l}\text { Surface } \\
\text { hydrophobicity }\end{array}$ & Pathogenicity \\
\hline$\Delta$ hum 2 & + & + & + \\
\hline$\Delta h u m 3$ & + & + & + \\
\hline$\Delta r s p l$ & + & + & + \\
\hline$\Delta r s p 2$ & + & + & + \\
\hline$\Delta$ hum3 3 repl & $(-)$ & - & + \\
\hline$\Delta$ hum $3 \Delta$ hum 2 & + & + & + \\
\hline$\Delta h u m 3 \Delta r s p 1$ & + & + & - \\
\hline
\end{tabular}

Effects on development and surface hydrophobicity of aerial hyphae as well as pathogenicity are indicated

Table 5 Pathogenicity of gene disruption mutants

\begin{tabular}{|c|c|c|c|}
\hline Inoculum & \# plants & \# tumors & $\begin{array}{l}\text { Tumors } \\
(\%)\end{array}$ \\
\hline $518(a 2 b 2) \times 521(a 1 b 1)$ & 29 & 26 & 89 \\
\hline $518 \Delta$ hum $2 \times 521 \Delta$ hum 2 & 25 & 19 & 82 \\
\hline $518 \Delta$ hum $3 \times 521 \Delta$ hum 3 & 25 & 22 & 92 \\
\hline $518 \Delta r s p 1 \times 521 \Delta r s p 1$ & 29 & 27 & 93 \\
\hline $518 \Delta r s p 2 \times 521 \Delta r s p 2$ & 36 & 31 & 86 \\
\hline $518 \Delta$ hum $3 \Delta r s p 1 \times 521 \Delta$ hum $3 \Delta r s p 1$ & 192 & 0 & 0 \\
\hline $518 \Delta$ hит $3 \Delta$ hит $2 \times 521 \Delta$ hит $3 \Delta$ hит 2 & 30 & 27 & 90 \\
\hline $518 \Delta$ hum $3 \Delta$ rep $1 \times 521 \Delta$ hum $3 \Delta$ repl & 28 & 24 & 86 \\
\hline
\end{tabular}

$-1633 b p$

Interestingly, the combined deletion of hum 3 and the repellent-like $r s p 1$ had a strong effect. Despite normal development of dikaryotic hyphae (Fig. 5c), we found a complete loss of pathogenicity of the $\Delta h u m 3 \Delta r s p l$ strains (Table 5). To verify this phenotype three independent a $2 \mathrm{~b} 2$

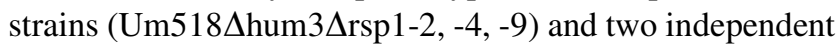
a1b1 strains (Um521 $\Delta$ hum $3 \Delta$ rsp1-16, -19) were analyzed by infecting maize plants with four combinations of compatible

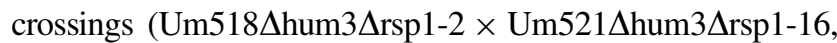

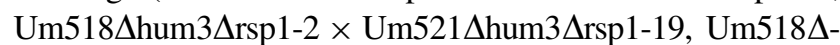
hum3 $\Delta$ rsp1-9 $\times$ Um521 $\Delta$ hum3 $\Delta$ rsp1-19, Um518 $\Delta$ hum3 $\Delta$ rsp1-5 $\times$ Um521 $\Delta$ hum3 $\Delta$ rsp1-19).

In the early infection phase $24 \mathrm{~h}$ after inoculation, no difference in filamentous growth and appressoria formation was found between the mutant and wild type strains (Fig. 6a). Subsequently, as investigated by Chlorazol Black E stained leaves 4 days after infection, the mutant was still 

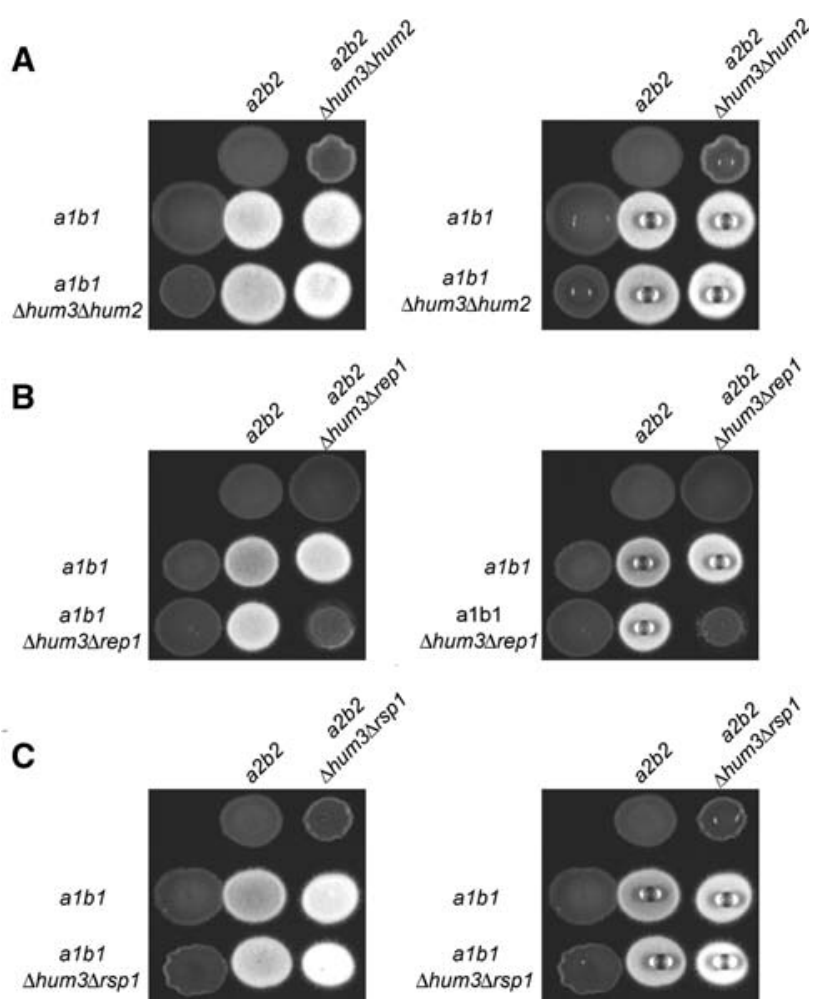

Fig. 5 Filamentous growth and surface hydrophobicity of $\Delta$ hum $3 \Delta$ hum 2 (a), $\Delta$ hum $3 \Delta$ repl (b) and $\Delta$ hum $3 \Delta r s p 1$ (c) mutants. Compatible strains were spotted on PD media containing $1 \%$ charcoal and incubated at $22^{\circ} \mathrm{C}$ for $48 \mathrm{~h}$. Wild type strains Um518 and Um521 were used as controls. The occurrence of white fuzzy colonies indicate mating and development of dikaryotic aerial mycelium. Cell surface hydrophobicity was monitored by placing a $5 \mu \mathrm{l}$ drop of water in the centre of a colony. $\Delta$ hum $3 \Delta$ repl strains show a severe defect in filament formation leading to strong reduction of surface hydrophobicity while $\Delta h u m 3 \Delta h u m 2$ and $\Delta h u m 3 \Delta r s p 1$ show no difference to the wild type

able to penetrate (Fig. 6b), but hyphal growth inside the plant tissue stopped very early and hyphae passing more than four tissue cells were never observed (Fig. 6c, d). Strong proliferation and branching of the invasive dicaryon which can usually be detected during wild type infections was completely abolished (Fig. 6d, e). Maize leaves exhibited local chloroses and necroses and appeared to be locally shriveled 4 days after infection but no further disease symptoms arose at later time points in infection (Fig. 7a). To elucidate whether the early growth arrest of intracellular hyphae was caused by a reactive oxygen species (ROS)mediated plant defense reaction, $\mathrm{H}_{2} \mathrm{O}_{2}$ was analyzed in infected tissue at time points from 1 up to 4 days after infection. However, similar to infection with wild type, no significant accumulation of $\mathrm{H}_{2} \mathrm{O}_{2}$ could be observed in the vicinity of penetrating hyphae of the $\Delta h u m 3 \Delta r s p 1$ mutant (data not shown). The $\Delta$ hum $3 \Delta r s p 1$ double knock-out strains arrested growth early after plant penetration, and, consequently, were completely unable to induce anthocyanin and tumor formation on infected maize plants (Fig. 7b). This complete loss of pathogenicity was observed irrespective of how the plants were infected, either by drop inoculation or by injection.

\section{Discussion}

As a biotrophic fungus, U. maydis does not trigger a typical host defense response when infecting maize plants. Evading the host's surveillance system or overcoming resistance likely requires specific extracellular effector proteins and/or surface-localized factors. We have applied the yeast signal sequence trap method to isolate proteins targeted to the secretory pathway and identified several proteins of the hydrophobin and repellent classes. While single deletions of any of the hydrophobin or repellent-like genes did not affect pathogenicity of $U$. maydis (Wosten et al. 1996; Teertstra et al. 2006), the combined knock-out of hum 3 and rspl yielded completely non-virulent mutant strains. These mutant strains exhibit no aberrant phenotypes when grown in vitro, and mating, filamentous growth and surface hydrophobicity are unchanged in comparison with the wild type. In contrast, most other $U$. maydis mutants with reduced virulence described previously are in fact impaired in mating, which is indispensable for the pathogenic development. Hum 3 and RSP1 represent, therefore, the first good candidates for "true" virulence factors in U. maydis. Recently, genomic clustering of a significant fraction of genes encoding secreted proteins in the $U$. maydis genomic sequence has been discovered, and a role of five of theses clusters in the pathogenic development has been proven by deletion of individual clusters (Kamper et al. 2006). None of these deletion strains were altered in morphology, growth, mating or development of aerial hyphae. Individual clusters therefore might represent virulence factors as a whole, or might contain single genes encoding virulence factors. While these gene clusters comprise approximately a fifth of all genes for predicted secreted proteins in the $U$. maydis genome, hum 3 and $r s p 1$ and notably none of the hydrophobin- or repellent-like genes are found in these clusters (Kamper et al. 2006).

Hum3 is an unusual protein composed of a C-terminal domain with characteristics of class I hydrophobins, including eight cysteine residues in conserved positions, and an $\mathrm{N}$-terminal domain containing 17 amphipathic repeats separated by putative Kex 2 processing site motifs. The repeat regions have a hydropathy profile similar to the repellent class of proteins (Wosten et al. 1996). Hydrophobins and repellent proteins do not share any sequence homologies or other structural similarities. Nevertheless, these two classes of proteins are proposed to fulfill partly redundant functions. Both are implicated in modulating 

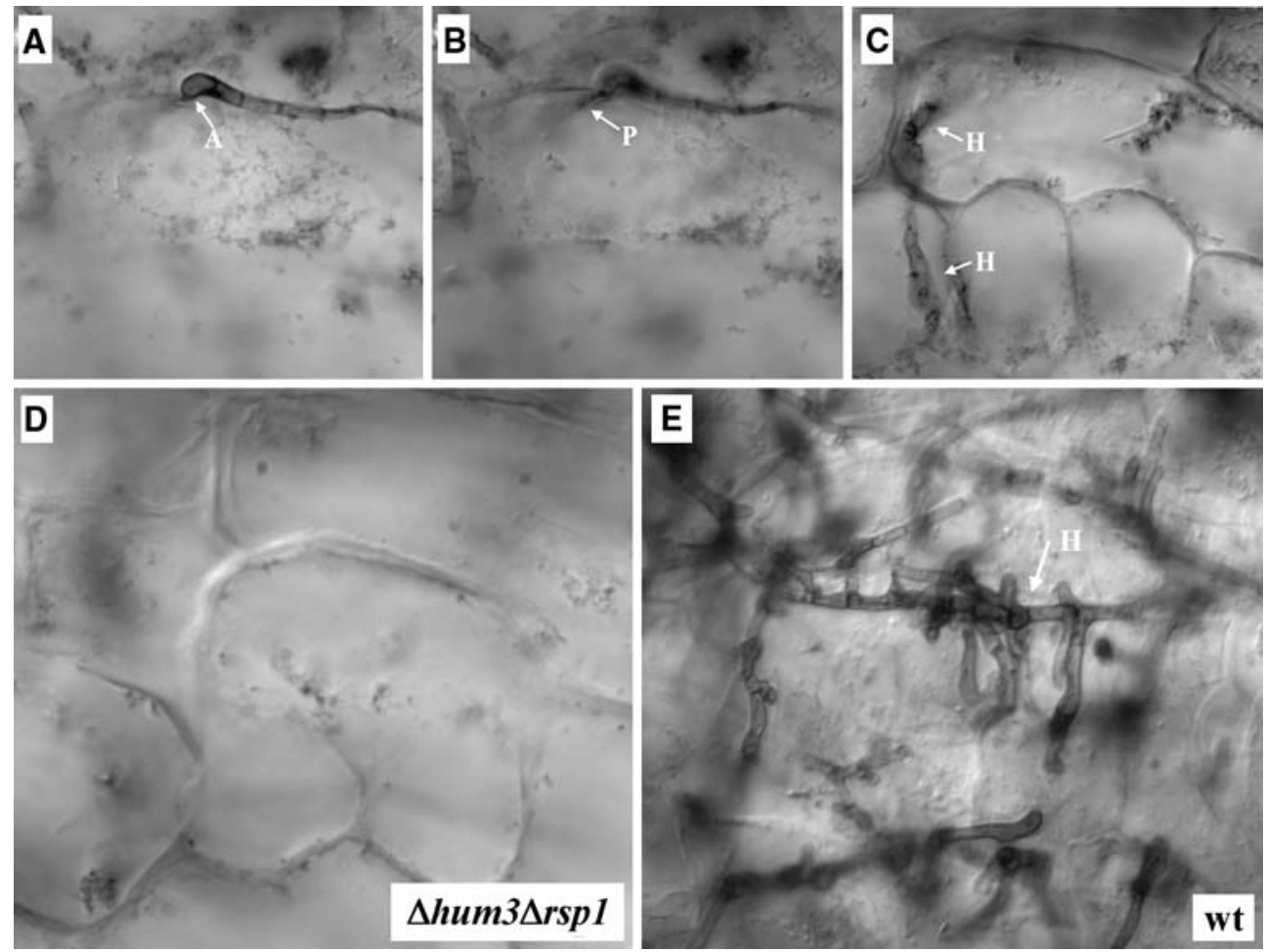

Fig. 6 Development of $\Delta$ hum $3 \Delta r s p l$ strains after infection. Maize leaves were detached $4 \mathrm{dpi}$ and stained with chlorazol. Focus from the cuticle towards the inner leaf tissue (from a to d) shows the development of the infectious dikaryon before and after penetration. a Filamentous growth and appressoria formation on maize leaves is not compromised in the double mutant strain $\Delta h u m 3 \Delta r s p 1$. b The mutant strain is still able to penetrate the plant cuticle. $\mathbf{c}$ Intercellularly growing dicaryothic hyphae develop, but arrest growth early after penetra-

tion. Up to this stage, infectious development of wild type strains is indistinguishable from the development of the $\Delta$ hum $3 \Delta r s p 1$ mutant, except for hyphal branching, which was never observed after infection with the $\Delta$ hum $3 \Delta r s p 1$ mutant. d No fungal material can be found in deeper cell layers of the maize mesophyll. e In the same focal plane as panel d, extensive proliferation and ramification of wild type hyphae can be observed. A Appressorium, $H$ Hyphae, $P$ Penetration hyphae

Fig. 7 Pathogenicity of

$\Delta$ hum $3 \Delta$ rspl double mutants.

7 day old maize plants were infected by injection (a) and 14 days old plants by drop infection (b) with cell suspensions of compatible Um $\Delta$ hum $3 \Delta r s p 1$ and wild type strains, respectively. a Four days after infection maize leaves exhibited local chloroses and necroses and appeared to be locally shriveled but no further disease symptoms arose 16 days after infection $\mathbf{b}$ Maize plants infected with $U$. maydis wild type control developed severe pathogenicity symptoms including anthocyan and tumor formation 14 days after infection. In contrast plant infected with $\Delta$ hum $3 \Delta r s p 1$ developed no disease symptoms $a 1 b 1 \times a 2 b 2$

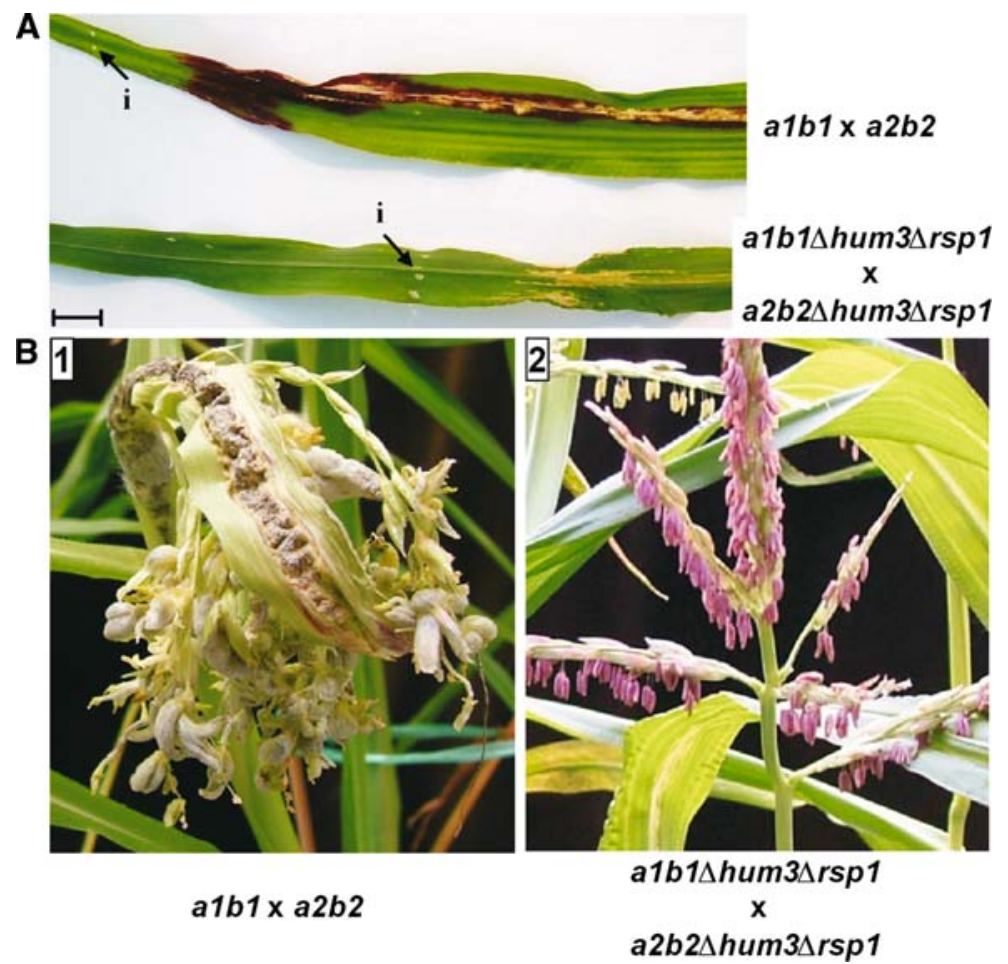

$a 2 b 2 \Delta h u m 3 \Delta r s p 1$ 
the surface properties of fungal hyphae either with respect to the attachment to hydrophobic structures and aerial growth of hyphae, or with respect to morphogenesis and pathogenicity (Kershaw and Talbot 1998; Wosten et al. 1996). Recently, it has been shown that in U. maydis hydrophobins have in part been functionally replaced by repellents (Teertstra et al. 2006). An involvement of hydrophobins and repellent proteins in pathogenicity of $U$. maydis, however, has not been demonstrated, so far (Kershaw and Talbot 1998; Teertstra et al. 2006; Wosten et al. 1996). Our finding that the simultaneous knock-out of hum 3 and rsp 1 leads to complete loss of pathogenicity supports the notion of cooperative or redundant functions of these two structurally divers classes of proteins and is first evidence for an essential role of hydrophobins and repellent-like proteins in the pathogenic development of $U$. maydis.

Hydrophobins are increasingly recognized as possible morphological determinants playing a role in pathogenicity as well as in development, being not simply hydrophobic coat proteins (Elliot and Talbot 2004). Hydrophobins constitute a large percentage of the proteins that cover spores and hyphal surfaces, and probably mediate the interaction of fungi with hydrophobic surfaces (Kershaw and Talbot 1998; Wosten et al. 1994; Wosten 2001). Despite considerable interest in hydrophobin function in phytopathogenic fungi and despite the isolation of numerous hydrophobin genes, to date there are only few reports of a functional involvement of hydrophobins in pathogenic development.

Two hydrophobins from Magnaporthe grisea, $\mathrm{Mpg} 1$ and Mhp1, have been implicated in conidial development, viability and pathogenic development (Kim et al. 2005; Talbot et al. 1993, 1996). Knock out of either of the genes leads to strongly reduced formation of appressoria and consequently to strongly reduced pathogenicity. While in the case of the $\Delta m p g 1$ mutant exogenous addition of cAMP could restore appressorium formation, this was not observed in the case of the $\Delta m p h 1$ mutant. It was therefore concluded, that both hydrophobins are involved in appressorium formation, but they function differently (Kim et al. 2005). Recently, cryparin, a hydrophobin of the chestnut blight fungus Cryphonectria parasitica, has been shown to be essential for stromal pustule eruption, a late stage of pathogenic development (Kazmierczak et al. 2005). These examples illustrate the wide variety of functions hydrophobins can have in pathogenic development of biotrophic fungi ranging from very early stages of infection to developmental processes at the very end of the infection cycle.

The mutant strains of $U$. maydis deleted in rsp1/hum 3 described in this study exhibited aberrations only in structures that develop in intimate contact with the host plant. While mating, growth of aerial hyphae, appressoria formation and penetration are not impaired, pathogenic development is blocked at early stages after penetration.
What actually causes the growth arrest of this mutant is not clear, so far. One possibility could be that hydrophobins and repellent-like proteins contribute to the disguise necessary for $U$. maydis to evade the host surveillance and defense systems. Despite many years of research, little is known about host defense responses to infection by $U$. maydis. Infection does not trigger classical defense responses of the host plants indicating that biotrophic fungi apparently either operate in a form of "stealth mode" or actively suppress the host defense machineries. We made the observation that maize plants infected with the mutant strains developed necrotic spots at the infection site, suggesting that wild type and mutants are recognized by the host plant differently. We examined the accumulation of reactive oxygen as an indication of a potential hypersensitive response of the plant upon penetration by the mutant fungal appressorium. However, in comparison with wildtype, no significant difference in production of $\mathrm{H}_{2} \mathrm{O}_{2}$ was observed. Thus further studies will be required to reveal whether the growth arrest may be due to altered surface properties of the mutant strains that remove the disguise that shields wild type strains, or whether Rsp1 and Hum3 are essential for actively suppressing plant defense mechanisms. Whatever the exact function of Hum 3 and Rsp1 in this context is, our results demonstrate an important role of hydrophobins and secreted repetitive proteins in signaling processes at the plant-fungus interface.

Interestingly, in ectomycorrhizal symbiosis, genes encoding hydrophobins and mannoproteins are specifically expressed in early symbiotic development (Duplessis et al. 2005). The symbiotic associations of plant roots and fungi can be paralleled with processes in pathogenic interactions between plant and biotrophic fungi. Insight into the mechanisms of how hydrophobins fulfill their functions might therefore be instrumental in understanding potential conserved basic mechanisms of these different plant-fungus interactions.

In conclusion, our integrated approach to identify proteins targeted to the secretory pathway in a biotrophic phytopathogenic fungus has proven to be a promising tool allowing the identification of pathogenicity genes in a very efficient way. Hum 3 and Rsp1 are interesting candidates for morphogenic proteins directly involved in early stages of pathogenic development of $U$. maydis. Further investigation of hydrophobins and repellent-like proteins with respect to the regulatory mechanisms of their expression and secretion will likely contribute to a deeper understanding of how the complex signaling networks actually drive morphogenesis and pathogenic development. Moreover, insight into the complex composition of the plant-fungus interface might reveal promising targets that could be used to devise novel strategies to develop antifungal drugs. Extracellular pathogenicity proteins like hydrophobins or 
repellent proteins may be easily accessible for drugs, circumventing the need to enter the cell, which sometimes forms an obstacle in the development of fungicidal compounds. Furthermore, interfering with protein functions essential for early stages of pathogenic development may offer the additional advantage of blocking fungal development prior to infection thus avoiding plant damage.

Acknowledgment We would like to thank Francesco Salamini and Maarten Koornneef for support, and Moola Mutondo and Jörg Kämper for critical reading the manuscript. The work was supported by grants from the Max Planck Society and Bayer Crop Science.

\section{References}

Ausubel FM, Brenz R, Kingston RE, Moore DD, Seidman JG, Smith JA, Strukl K (1987) Current protocols in molecular biology. Wiley, USA

Banuett $\mathrm{F}$ (1995) Genetics of Ustilago maydis, a fungal pathogen that induces tumors in maize. Annu Rev Genet 29:179-208

Banuett F, Herskowitz I (1989) Different a alleles of Ustilago maydis are necessary for maintenance of filamentous growth but not for meiosis. Proc Natl Acad Sci USA 86:5878-5882

Banuett F, Herskowitz I (1996) Discrete developmental stages during teliospore formation in the corn smut fungus, Ustilago maydis. Development 122:2965-2976

Basse CW, Steinberg G (2004) Ustilago maydis, model system for analysis of the molecular basis of fungal pathogenicity. Mol Plant Pathol 5:83-92

Basse CW, Stumpferl S, Kahmann R (2000) Characterization of a Ustilago maydis gene specifically induced during the biotrophic phase: evidence for negative as well as positive regulation. Mol Cell Biol 20:329-339

Bendtsen JD, Nielsen H, von Heijne G, Brunak S (2004) Improved prediction of signal peptides: SignalP 3.0. J Mol Biol 340:783795

Bolker M, Urban M, Kahmann R (1992) The a mating type locus of $U$. maydis specifies cell signaling components. Cell 68:441-450

Brachmann A, Schirawski J, Muller P, Kahmann R (2003) An unusual MAP kinase is required for efficient penetration of the plant surface by Ustilago maydis. Embo J 22:2199-2210

Brachmann A, Weinzierl G, Kamper J, Kahmann R (2001) Identification of genes in the $\mathrm{bW} / \mathrm{bE}$ regulatory cascade in Ustilago maydis. Mol Microbiol 42:1047-1063

Christensen JJ (1963) Corn smut induced by Ustilago maydis. Am Phytopathol Soc Monogr 2

Clergeot PH, Gourgues M, Cots J, Laurans F, Latorse MP, Pepin R, Tharreau D, Notteghem JL, Lebrun MH (2001) PLS1, a gene encoding a tetraspanin-like protein, is required for penetration of rice leaf by the fungal pathogen Magnaporthe grisea. Proc Natl Acad Sci USA 98:6963-6968

Dean RA, Talbot NJ, Ebbole DJ, Farman ML, Mitchell TK, Orbach MJ, Thon M, Kulkarni R, Xu JR, Pan H, Read ND, Lee YH, Carbone I, Brown D, Oh YY, Donofrio N, Jeong JS, Soanes DM, Djonovic S, Kolomiets E, Rehmeyer C, Li W, Harding M, Kim S, Lebrun MH, Bohnert H, Coughlan S, Butler J, Calvo S, Ma LJ, Nicol R, Purcell S, Nusbaum C, Galagan JE, Birren BW (2005) The genome sequence of the rice blast fungus Magnaporthe grisea. Nature 434:980-986

Duplessis S, Courty PE, Tagu D, Martin F (2005) Transcript patterns associated with ectomycorrhiza development in Eucalyptus globulus and Pisolithus microcarpus. New Phytol 165:599-611
Elliot MA, Talbot NJ (2004) Building filaments in the air: aerial morphogenesis in bacteria and fungi. Curr Opin Microbiol 7:594-601

Feldbrugge M, Kamper J, Steinberg G, Kahmann R (2004) Regulation of mating and pathogenic development in Ustilago maydis. Curr Opin Microbiol 7:666-672

Gietz RD, Schiestl RH, Willems AR, Woods RA (1995) Studies on the transformation of intact yeast cells by the LiAc/SS-DNA/PEG procedure. Yeast 11:355-360

Gillissen B, Bergemann J, Sandmann C, Schroeer B, Bolker M, Kahmann R (1992) A two-component regulatory system for self/ non-self recognition in Ustilago maydis. Cell 68:647-657

Gourgues M, Brunet-Simon A, Lebrun MH, Levis C (2004) The tetraspanin BcPls1 is required for appressorium-mediated penetration of Botrytis cinerea into host plant leaves. Mol Microbiol 51:619629

Hahn M, Mendgen K (2001) Signal and nutrient exchange at biotrophic plant-fungus interfaces. Curr Opin Plant Biol 4:322-327

Hoffmann CS, Winston F (1987) A ten minute DNA preparation from yeast efficiently releases autonomous plasmids for transformation in E.coli. Gene 57:267-272

Holliday R (1961) The genetics of Ustilago maydis. Genet Res Camb 2:204-230

Kahmann R, Steinberg G, Basse C, Feldbrügge M, Kämper J (2000) Ustilago maydis, the causative agent of corn smut disease. In: Kronstad JW (ed) Fungal pathology. Kluwer, Dordrecht pp 347 371

Kahmann R, Kamper J (2004) Ustilago maydis: how its biology relates to pathogenic development. New Phytol 164:31-42

Kamper J (2004) A PCR-based system for highly efficient generation of gene replacement mutants in Ustilago maydis. Mol Genet Genom 271:103-110

Kamper J, Kahmann R, Bolker M, Ma LJ, Brefort T, Saville BJ, Banuett F, Kronstad JW, Gold SE, Muller O, Perlin MH, Wosten HA, de Vries R, Ruiz-Herrera J, Reynaga-Pena CG, Snetselaar K, McCann M, Perez-Martin J, Feldbrugge M, Basse CW, Steinberg G, Ibeas JI, Holloman W, Guzman P, Farman M, Stajich JE, Sentandreu R, Gonzalez-Prieto JM, Kennell JC, Molina L, Schirawski J, Mendoza-Mendoza A, Greilinger D, Munch K, Rossel N, Scherer M, Vranes M, Ladendorf O, Vincon V, Fuchs U, Sandrock B, Meng S, Ho EC, Cahill MJ, Boyce KJ, Klose J, Klosterman SJ, Deelstra HJ, Ortiz-Castellanos L, Li W, SanchezAlonso P, Schreier PH, Hauser-Hahn I, Vaupel M, Koopmann E, Friedrich G, Voss H, Schluter T, Margolis J, Platt D, Swimmer C, Gnirke A, Chen F, Vysotskaia V, Mannhaupt G, Guldener U, Munsterkotter M, Haase D, Oesterheld M, Mewes HW, Mauceli EW, DeCaprio D, Wade CM, Butler J, Young S, Jaffe DB, Calvo S, Nusbaum C, Galagan J, Birren BW (2006) Insights from the genome of the biotrophic fungal plant pathogen Ustilago maydis. Nature 444:97-101

Kazmierczak P, Kim DH, Turina M, Van Alfen NK (2005) A Hydrophobin of the chestnut blight fungus, Cryphonectria parasitica, is required for stromal pustule eruption. Eukaryot Cell 4:931-936

Kershaw MJ, Talbot NJ (1998) Hydrophobins and repellents: proteins with fundamental roles in fungal morphogenesis. Fungal Genet Biol 23:18-33

Kim S, Ahn IP, Rho HS, Lee YH (2005) MHP1, a Magnaporthe grisea hydrophobin gene, is required for fungal development and plant colonization. Mol Microbiol 57:1224-1237

Klein RD, Gu Q, Goddard A, Rosenthal A (1996) Selection for genes encoding secreted proteins and receptors. Proc Natl Acad Sci USA 93:7108-7113

Leuthner B, Aichinger C, Oehmen E, Koopmann E, Muller O, Muller $\mathrm{P}$, Kahmann R, Bolker M, Schreier PH (2005) $\mathrm{A} \mathrm{H}_{2} \mathrm{O}_{2}$-producing glyoxal oxidase is required for filamentous growth and pathogenicity in Ustilago maydis. Mol Genet Genom 272:639-650 
Lucas JA (2004) Survival, surfaces and susceptibility-the sensory biology of pathogens. Plant Pathol 53:679-691

Muller P, Aichinger C, Feldbrugge M, Kahmann R (1999) The MAP kinase kpp2 regulates mating and pathogenic development in Ustilago maydis. Mol Microbiol 34:1007-1017

Read ND, Kellock LJ, Collins TJ, Gundlach AM (1997) Role of topography sensing for infection-structure differentiation in cereal rust fungi. Planta 202:163-170

Romeis T, Brachmann A, Kahmann R, Kamper J (2000) Identification of a target gene for the bE-bW homeodomain protein complex in Ustilago maydis. Mol Microbiol 37:54-66

Sacadura NT, Saville BJ (2003) Gene expression and EST analyses of Ustilago maydis germinating teliospores. Fungal Genet Biol 40:47-64

Sambrook J, Fritsch EF, Maniatis T (1989) Molecular cloning: a. laboratory manual. Cold Spring Harbor Laboratory Press, Cold Spring Harbor

Schulz B, Banuett F, Dahl M, Schlesinger R, Schafer W, Martin T, Herskowitz I, Kahmann R (1990) The b alleles of U. maydis, whose combinations program pathogenic development, code for polypeptides containing a homeodomain-related motif. Cell 60:295-306

Snetselaar KM, Mims CW (1993) Infection of Maize Stigmas by Ustilago maydis-Light and Electron-Microscopy. Phytopathology 83:843-850

Spellig T, Bottin A, Kahmann R (1996) Green fluorescent protein (GFP) as a new vital marker in the phytopathogenic fungus $U s t i-$ lago maydis. Mol Gen Genet 252:503-509

Talbot NJ, Ebbole DJ, Hamer JE (1993) Identification and characterization of MPG1, a gene involved in pathogenicity from the rice blast fungus Magnaporthe grisea. Plant Cell 5:1575-1590

Talbot NJ, Kershaw MJ, Wakley GE, De Vries O, Wessels J, Hamer JE (1996) MPG1 encodes a fungal hydrophobin involved in surface interactions during infection-related development of Magnaporthe grisea. Plant Cell 8:985-999
Teertstra WR, Deelstra HJ, Vranes M, Bohlmann R, Kahmann R, Kamper J, Wosten HA (2006) Repellents have functionally replaced hydrophobins in mediating attachment to a hydrophobic surface and in formation of hydrophobic aerial hyphae in Ustilago maydis. Microbiology 152:3607-3612

Thordal-Christensen H, Zhang Z, Wei Y, Collinge DB (1997) Subcellular localization of $\mathrm{H}_{2} \mathrm{O}_{2}$ in plants. $\mathrm{H}_{2} \mathrm{O}_{2}$ accumulation in papillae and hypersensitive response during the barley-powdery mildew interaction. Plant J 11:1187-1194

Torto TA, Li S, Styer A, Huitema E, Testa A, Gow NA, van West P, Kamoun S (2003) EST mining and functional expression assays identify extracellular effector proteins from the plant pathogen Phytophthora. Genome Res 13:1675-1685

Tsukuda T, Carleton S, Fotheringham S, Holloman WK (1988) Isolation and characterization of an autonomously replicating sequence from Ustilago maydis. Mol Cell Biol 8:3703-3709

Tucker SL, Talbot NJ (2001) Surface attachment and pre-penetration stage development by plant pathogenic fungi. Annu Rev Phytopathol 39:385-417

Tucker SL, Thornton CR, Tasker K, Jacob C, Giles G, Egan M, Talbot $\mathrm{NJ}$ (2004) A fungal metallothionein is required for pathogenicity of Magnaporthe grisea. Plant Cell 16:1575-1588

Veneault-Fourrey C, Parisot D, Gourgues M, Lauge R, Lebrun MH, Langin T (2005) The tetraspanin gene CIPLS1 is essential for appressorium-mediated penetration of the fungal pathogen $\mathrm{Col}$ letotrichum lindemuthianum. Fungal Genet Biol 42:306-318

Wosten HA (2001) Hydrophobins: multipurpose proteins. Annu Rev Microbiol 55:625-646

Wosten HA, Bohlmann R, Eckerskorn C, Lottspeich F, Bolker M, Kahmann R (1996) A novel class of small amphipathic peptides affect aerial hyphal growth and surface hydrophobicity in Ustilago maydis. Embo J 15:4274-4281

Wosten HA, Schuren FH, Wessels JG (1994) Interfacial self-assembly of a hydrophobin into an amphipathic protein membrane mediates fungal attachment to hydrophobic surfaces. Embo J 13:5848-5854 